\title{
Antioxidant, Anti-inflammatory, Cytotoxic and Analgesic Activities of Sensevieria trifasciata
}

\author{
Sagorika Sing Pinky, Sirajum Monira, Md. Akbar Hossain and Amir Hossain \\ Department of Pharmacy, ASA University Bangladesh, Shaymoli, Dhaka, Bangladesh
}

(Received: July 2, 2020; Accepted: July 21, 2020, 2019; Published (web): July 25, 2020)

\begin{abstract}
Sansevieria trifasciata is a common perennial ornamental plant which freely grows and widely found in homes, parks, and woodlands. Traditionally, this plant has been used against acne, allergy, helminths and fungal infections. In the present study, the ethanolic extract of leaves of Sansevieria trifasciata (STET) has been used to study the phytoconstituents and several bioactivities. In vitro antioxidant activity of STET has been determined by DPPH scavenging assay and measuring the total tannins and phenolic contents. Anti-inflammatory activity has been evaluated by hypotonic solution and heat induced hemolysis. Moreover, cytotoxic and analgesic activities have also been evaluated by brine shrimp lethality assay and acetic acid induced writhing inhibition method, respectively. STET confirmed the presence of reducing sugar, combined reducing sugar, tannins, flavonoids, glycosides, proteins and steroids. In DPPH scavenging assay, STET revealed the $\mathrm{IC}_{50}$ value $2.19 \mu \mathrm{g} / \mathrm{ml}$ whereas the standard showed $1.39 \mu \mathrm{g} / \mathrm{ml}$. In addition, the total tannins and total phenolic contents were found to be $10.78 \mathrm{mg}$ and $31.99 \mathrm{mg} \mathrm{GAE} / \mathrm{g}$ of dried plant extract, respectively. In hypotonic solution induced hemolysis test, the plant extract exhibited 39.27, 37.04 and $33.19 \%$ inhibition at $0.5,1.0$ and $2.0 \mathrm{mg} / \mathrm{ml}$ concentration where the reference standard displayed $30.57 \%$ inhibition. In heat-induced hemolysis, the STET also displayed $34.25 \%$ inhibition of hemolysis at $1 \mathrm{mg} / \mathrm{ml}$. Furthermore, in analgesic and cytotoxic activity tests, STET showed potential activities in a dose dependent manner. The results of the present studies suggest that STET has antioxidant, anti-inflammatory, cytotoxic and analgesic activities.
\end{abstract}

Key words: Sensevieria trifasciata, antioxidant, anti-inflammatory, cytotoxic, analgesic.

\section{Introduction}

Medicinal plants are proved, in different studies, to be beneficial against numerous disorders. Approximately one fourth of prescribed drugs accounts for plant origin and more than three quarter people depends on medicines that are derived from medicinal plants (Hoareau and DaSilva, 1999; Das et al., 2011). To begin with the overview of medicines, man reclined on the healing belongings of medicinal plants (Ahvazi et al., 2012). Some people worth these plants due to the ancient confidence speaks plants are bent to supply man with food, medical treatment, and other properties. Almost all philosophies from early time to the present day have recycled plants as a source of medicine (Kokwaro, 2009). However, In living organisms, the both ROS (reactive oxygen species) and RNS (reactive nitrogen species) are known to cause damage to lipids, proteins, enzymes, and nucleic acids leading to some ailments such as neurodegenerative disease, cancer, aging, malaria, atherosclerosis, diabetes, liver injury, Alzheimer, Parkinson, and some others pathological events (Duan et al., 2006).

Sensevieria trifasciata (Family-Asparagaceae) is recognized by many names including mother-inlaw's tongue, snake plant (English). It is an evergreen, succulent, perennial plant producing long, narrow, erect or slightly spreading sword-shaped leaves up to $75 \mathrm{~cm}$ long from a rhizomatous rootstock. The plant is cultivated for its fiber in several tropical countries, it is also harvested from the wild for local medicinal use. It is commonly

Corresponding author: Amir Hossain; Tel.: +880 1715 646476; Email: hellotoamir@gmail.com

DOI: https://doi.org/10.3329/bpj.v23i1.48341 
grown as an ornamental plant in tropical and subtropical regions, and as a pot plant in many other areas of the world (Rwawiire and Tomkova, 2015). In a study, antiallergic and anti-anaphylactic activities of ethanolic extract of Sensevieria trifasciata leaves have been evaluated (Andhare et al., 2012). Mechanism of antidiabetic potentials has also been studied (Dey et al., 2014). In addition, toxicity status and anti-ulcerative activity have also been investigated (Ighodaro et al., 2017). In some other literatures, thrombolytic (Sikder et al., 2011), analgesic and antipyretic (Anbu et al., 2009) activities of the plant extract have been evaluated. In this context, we hypothesize that the leaf extracts of this plant might possess some compounds with antioxidant, cytotoxic, analgesic and membrane stabilizing activities.

\section{Materials and Methods}

Plant collection and extraction: S. trifasciata leaf was collected from Botanical garden Bangladesh in July 2018 and was recognized by the Bangladesh National Herbarium (BNH), Mirpur-1, Dhaka-1216 (voucher specimen no: DACB-45930).

$$
\text { Phytochemical screening: Several }
$$
phytochemicals in STET, for example, reducing sugar have been identified by Fehling's solution and Benedict's reagent, alkaloid with Mayer's and Dragendroff's reagent, saponins with distilled water, glycosides with sodium hydroxide solution, steroids with $\mathrm{H}_{2} \mathrm{SO}_{4}$, tannins with ferric chloride and potassium dichromate, gum with Molisch reagent described by Ghani (2003).

Estimation of total phenolics and total tannins: Folin-Ciocalteu (FC) technique was implemented on the extract to identify the amount of phenolic and tannin content described previously (Hossain et. al., 2016; Islam et al., 2015).

$D P P H$ Scavenging assay: In this test, the antioxidant activity of STET described by Sumi et.al. (2016) was estimated by DPPH free radical scavenging assay taking butylated hydroxytoluene (BHT) as standard.
Anti-inflammatory activity analysis: The antiinflammatory activity of the STET has been evaluated following Shinde et al. (1999) by both hypotonic solution-induced hemolysis and heatinduced hemolysis of human erythrocytes taking indomethacin as standard.

Brine Shrimp Lethality Bioassay: Cytotoxic activity of STET was measured by brine-shrimp lethality bioassay where Artemia salina was used to perform this test (Meyer et al., 1982; Hossain et al., 2016).

Analgesic Activity evaluation: This test was performed by acetic acid induced writhing inhibition in mice of either sex $(n=5)$ balancing 18-22 gm that was previously described (Hasan et al., 2017).

Statistical analysis: All analyses were dual checked and passed in three replications. Mean \pm SEM value was used to represent the data. All new parameters were evaluated for their consequence level by correlation and the t-tests $(P<0.05)$ was used.

\section{Results and Discussion}

Phytochemical screening: Phytochemical screening of STET showed the presence of reducing sugar, combined reducing sugar, tannins, flavonoids, glycosides, proteins and steroids which is summarized in Table 1.

Table 1. Phytochemical group test of $S$. trifasciata leaf extract.

\begin{tabular}{lc}
\hline Phytochemical Group & Result \\
\hline Reducing sugar & + \\
Combined reducing sugar & + \\
Tannins & + \\
Flavonoids & + \\
Saponin & + \\
Gums & - \\
Steroids & + \\
Alkaloids & + \\
Glycoside & + \\
Proteins & + \\
Acidic compounds & - \\
\hline
\end{tabular}

(+) indicates Presence; (-) indicates Absence 
Total phenolic and tannin contents: The total tannin and phenolic contents were found to be 10.78 $\mathrm{mg}$ and $31.99 \mathrm{mg} \mathrm{GAE} / \mathrm{g}$ of dried plant extract, respectively. The polyphenolic content of plant extract is represented in Table 2.

Table 2. Polyphenolic content of ethanol extract of $S$. trifasciata.

\begin{tabular}{ll}
\hline Polyphenolic compounds & Content $(\mathrm{mg})$ \\
\hline Total tannin & $10.78 \pm 0.007$ \\
Total phenolic & $31.99 \pm 0.001$ \\
\hline
\end{tabular}

Here, each value represents the average of three analysis \pm standard error of mean expressed in terms of $\mathrm{mg} \mathrm{GAE} / \mathrm{g}$ dried plant extract.
$D P P H$ free radical scavenging activity: The $\mathrm{IC}_{50}$ value was calculated and compared with ascorbic acid (Figure 1). $\mathrm{IC}_{50}$ value of STET was found to be $2.19 \mu \mathrm{g} / \mathrm{ml}$ whereas for standard ascorbic acid, it was $1.39 \mu \mathrm{g} / \mathrm{ml}$.

Anti-inflammatory activity: The membrane stabilizing activity by two methods is shown on Table 3. In hypotonic solution induced hemolysis test, the plant showed $39.27 \%, 37.04 \%$ and $33.19 \%$ inhibition at $0.5,1.0$ and $2.0 \mathrm{mg} / \mathrm{ml}$ concentration whereas standard displayed $30.57 \%$ inhibition. STET also displayed, in heat induced hemolysis, $34.25 \%$ inhibition of hemolysis at $1 \mathrm{mg} / \mathrm{ml}$ whereas standard (Indomethacin) showed $30.75 \%$.

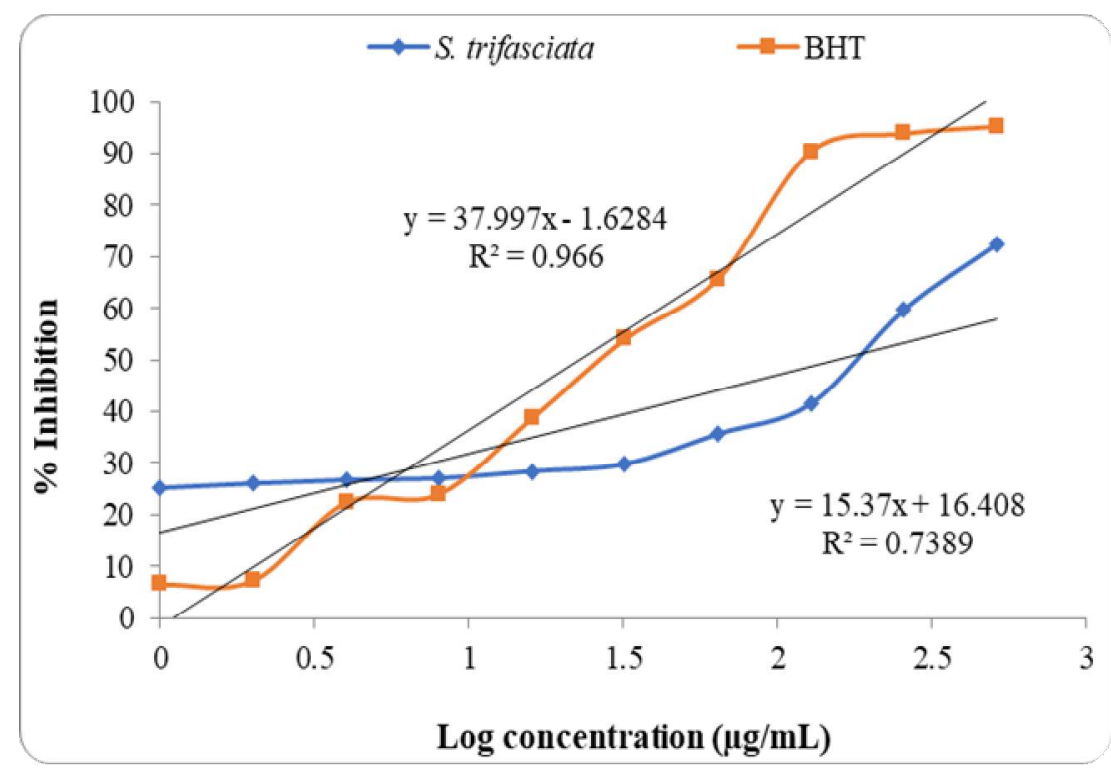

Figure 1. Comparison of $\%$ inhibition with log concentration for both standard (BHT: butylated hydroxytoluene) and $S$. trifasciata leaf extract.

Brine Shrimp Lethality Bioassay: The extract showed $\mathrm{LC}_{50}$ against brine shrimp nauplii at 58.67 $\mu \mathrm{g} / \mathrm{ml}$ whereas vincristine sulphate (standard) showed toxicity at $0.4854 \mu \mathrm{g} / \mathrm{ml}$.

Analgesic Activity: The results of the test showed that STET at the dose of $250 \mathrm{mg} / \mathrm{kg}$ and $500 \mathrm{mg} / \mathrm{kg}$ exhibit writhing reflex inhibition of $33.63 \%$ and $44.98 \%$, respectively while the standard (diclofenac
$\mathrm{Na}$ at dose $25 \mathrm{mg} / \mathrm{kg}$ ) drug showed $52.84 \%$ inhibition (Figure 2). The extract $(500 \mathrm{mg} / \mathrm{kg}$ ) and standard have been found statistically significant at $\mathrm{p}<0.05$.

Phenolic compounds act as free radical terminators as they belong to a class of antioxidant (Shahidi et al., 1992). Free radicals are known as major contributors of several clinical disorders such as diabetes mellitus, cancer, liver diseases, renal 
failure, and degenerative diseases because of deficient natural antioxidant defense mechanism (Parr and Bolwell, 2000). Previous report has shown that phenolic compounds have hydroxyl group which is responsible for free radical scavenging activity (Sumi et al., 2016). This free radical scavenging activity depends on the compound's molecular weight, presence of aromatic ring and nature of $\mathrm{OH}$ group's substitution (Hagerman et al., 1998). Another important category of phenolic compound are flavonoids which have good antioxidant activity. Flavonoid and its derivatives exert a varied range of anti-inflammatory, antibacterial, anticancer, antiviral and anti-allergic activities. It is also considered to be highly effective against oxidizing molecules like singlet oxygen and various free radicals responsible for several diseases (Ruan et al., 2008).

Table 3. Percent inhibition of hemolysis of ethanol leaf extracts of S. trifasciata.

\begin{tabular}{lccc}
\hline Sample code & Concentration & \multicolumn{2}{c}{ inhibition of hemolysis } \\
\cline { 3 - 4 } & & $\begin{array}{c}\text { Hypotonic solution-induced } \\
\text { hemolysis }\end{array}$ & $\begin{array}{c}\text { Heat-induced } \\
\text { hemolysis }\end{array}$ \\
\hline Hypotonic medium & $50 \mathrm{mM}$ & 2.47 & -- \\
Extract & $2.0 \mathrm{mg} / \mathrm{ml}$ & 33.198 & 34.25 \\
& $1.0 \mathrm{mg} / \mathrm{ml}$ & 37.044 & \\
Standard & $0.05 \mathrm{mg} / \mathrm{ml}$ & 39.27 & 30.75 \\
(Indomethacin) & $0.1 \mathrm{mg} / \mathrm{ml}$ & 30.57 & \\
\hline
\end{tabular}

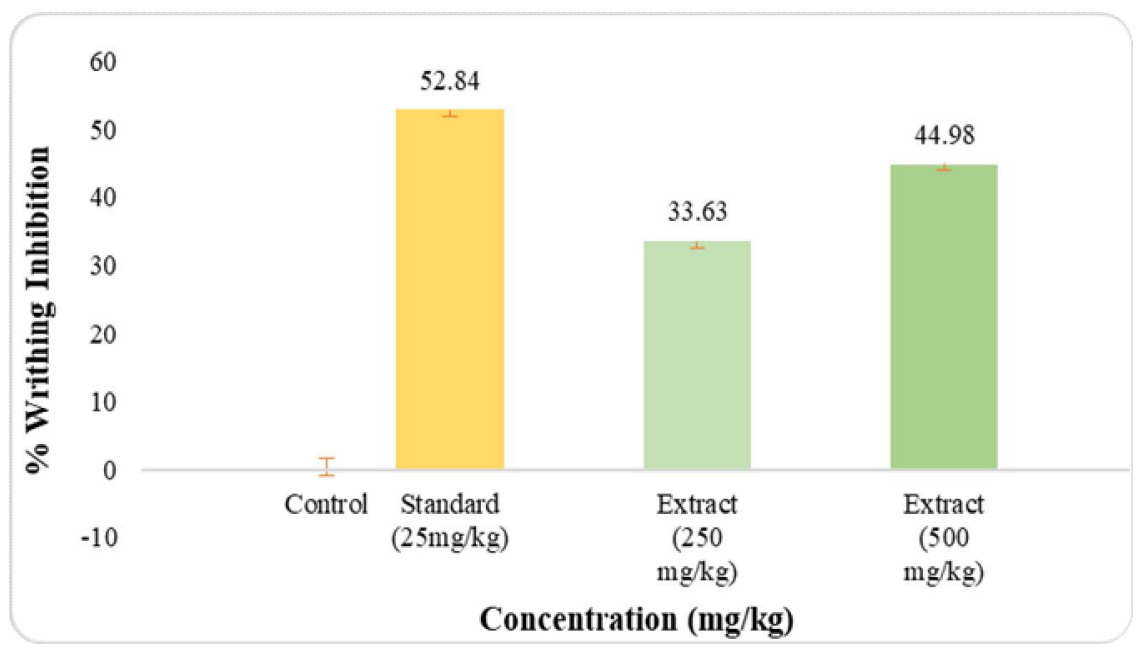

Figure 2. Percent writhing inhibition by the standard (diclofenac Na) and $S$. trifasciata leaf extract. The extract $(500 \mathrm{mg} / \mathrm{kg})$ and standard have been found statistically significant at $\mathrm{p}<0.05$.

It is found from the present study, STET contains a good amount of tannins which form complex with proteins and other macromolecules as they contain hydroxyl groups and free radicals (AfifyAel et al., 2012). Previous report has shown that tannins have antioxidant activity (Zhang and Lin, 2008). By donating hydrogen from hydroxyl group, antioxidants intercept the free radical chain reaction and form stable product. This product does not initiate or propagate further oxidation of lipid (Hadbaoui et al., 2010). In such way, free radicals hinder cell damage. Besides, tannins have astringent properties. Tannins may act as a beneficial source of protein, but on the contrary, because of its 
unpredictable amount, it may also cause toxicity and may also lead animals to death (Yang and Russell, 1992). The present study suggests that, the STET possesses a handsome amount of tannin content which refers further research for the protection of cell using free radicals.

The experiment also reveals that STET have anti-inflammatory activity which is evaluated by hypotonic solution induced hemolysis and heat induced hemolysis tests. It has been reported that flavonoids exert profound stabilizing effects on lysosomes both in vitro and in vivo in experimental animals (Omale et al., 2008) while tannin and saponins have the ability to bind cations and other biomolecules, and are able to stabilize the erythrocyte membrane (Omale et al., 2008). The high membrane stabilizing activity of the STET observed in this investigation may be due to its high tannin content.

Then, we carried out brine shrimp lethality bioassay which is a method to evaluate cytotoxic activity (Ahmed et al., 2013). The plant contains saponins which has been reported to have wide range of pharmacological activities, such as, bactericidal, antiviral, cytotoxic, and anti-cancer (Ksouri et al., 2009). It is also reported that there is correlation between brine shrimp lethality and cytotoxic activity (Mongelli et al., 1995). For brine shrimp lethality bioassay $\mathrm{LC}_{50}$ values lower than $1000 \mu \mathrm{g} / \mathrm{ml}$ were considered bioactive (Martin-Cordero et al., 1994). In our present study, STET showed a good lethality against brine shrimp compared to standard (vincristine sulphate) which needs further cell line assay for the evaluation of cytotoxic activity in more sensitive way.

Acetic acid induced by intraperitoneal route can cause pain by releasing prostaglandin $\mathrm{E}_{2}$ and lipoxygenase (Sulaiman et al., 2008). The STET may exert non-narcotic analgesic activity by the reduction of prostaglandin synthesis, includes writhing inhibition compared to that of standard diclofenac Na. As we know that the standard drug diclofenac sodium is a potent analgesic and it can produce stronger analgesic activity rather the ethanol leaf extract of S. trifasciata.

\section{Conclusions}

The ethanol extract of leaves of $S$. trifasciata has been confirmed the presence of reducing sugar, combined reducing sugar, tannins, flavonoids, glycosides, proteins, and steroids. In addition, the crude extract has potential antioxidant, cytotoxic, anti-inflammatory, and analgesic activities.

\section{Acknowledgments}

The authors are thankful to the Department of Pharmacy, ASA University Bangladesh for providing laboratory facilities and contributory support as well as chemicals and reagents. We also thank the authority of Bangladesh National Herbarium (BNH) for identification of the plant.

\section{Reference}

Afify Ael-M., E-BHS., El-Salam, S.M. and Omran, A.A. 2012. Biochemical changes in phenols, flavonoids, tannins, vitamin E, $\beta$-carotene and antioxidant activity during soaking of three white sorghum varieties. Asian Pac. J. Trop. Biomed. 2, 203-209.

Ahmed, J., Sultana, N., Dewan, S.M.R., Amin, M.N. and Uddin, S.M.N. 2013. Determination of chemical groups and investigation of anthelmintic, cytotoxic, and antibacterial activities of leaves of Cinnamomum Tamala (Family: Lauraceae). Int. J. Pharmamedix India. 1, 222-232.

Ahvazi, M., Khalighi-Sigaroodi, F., Charkhchiyan, M.M., Mojab, F., Mozaffarian, V.A. and Zakeri, H. 2012 Introduction of medicinal plants species with the most traditional usage in Alamut region. Iran J. Pharm. Res. 11, 185-94.

Anbu, J.S., Jayaraj, P., Varatharajan, R., Thomas, J., Jisha, J. and Muthappan, M. 2009. Analgesic and antipyretic effects of Sansevieria trifasciata leaves. Afr. J. Trad. Complement. Altern. Med. 6, 529.

Andhare, R.N., Raut, M.K. and Naik, S.R. 2012. Evaluation of antiallergic and anti-anaphylactic activity of ethanolic extract of Sanseveiria trifasciata leaves (EEST) in rodents. J. Ethnopharmacol. 142, 627-633.

Das, J., Mannan, A., Rahman, M.M., Dinar, M.A.M., Uddin, M.E., and Khan, I.N. 2011. Chloroform and ethanol extract of Spondias pinnata and its different pharmacological activity like- antioxidant, cytotoxic, antibacterial potential and phytochemical screening through in-vitro method. Int. J. Res. Pharma. Biomed. Sci. 2, 1806-1812. 
Dey, B., Bhattacharjee, R., Mitra, A., Singla, R.K. and Pal, A. 2014. Mechanistic explorations of antidiabetic potentials of Sansevieria trifasciata. Indo. Global J. Pharmaceut. Sci. 4, 113-122.

Duan, X.J., Zhang, W.W., Li, X.M. and Wang, B.G. 2006. Evaluation of antioxidant property of extract and fractions obtained from a red alga, Polysiphonia urceolata. Food Chem. 95, 37-43.

Ghani, A. 2003. Medicinal Plants of Bangladesh, 2nd edition, The Asiatic Society of Bangladesh, Dhaka. p. 603.

Hadbaoui, Z., Djeridane, A., Yousfi, M., Saidi, M. and Nadjemi, B. 2010 Jan. Fatty acid, tocopherol composition and the antioxidant activity of the lipid extract from the sorghum grains growing in Algeria. Med. J. Nutr. Metab. 3, 215-220.

Hagerman, A.E., Riedl, K.M., Jones, G.A., Sovik, K.N., Ritchard, N.T., Hartzfeld, P.W. and Riechel, T.L. 1998. May. High molecular weight plant polyphenolics (tannins) as biological antioxidants. $J$. Agric. Food Chem. 46, 1887-1892.

Hasan, M.M., Hossain, A., Shamim, A. and Rahman, M.M. 2017. Phytochemical and pharmacological evaluation of ethanolic extract of Lepisanthes rubiginosa $\mathrm{L}$. leaves. BMC Complement. Alter. Med. 17, 496.

Hoareau, L. and DaSilva, E.J. 1999. Medicinal plants: a reemerging health aid. Electron J. Biotech. 2, 3-4.

Hossain, A., Islam, F., Saifuzzaman, M., Saeed, M.A., Islam, M.K., Murshid, G.M. and Rahman, M.M. 2016 Bioactivity of Boehmeria macrophylla (Urticaceae) leaf extract. Orient. Pharm. Exp. Med. 16, 233-241.

Ighodaro, O.M., Adeosun, A.M., Ojiko, B.F., Akorede A.T. and Fuyi-Williams, O. 2017. Toxicity status and antiulcerative potential of Sansevieria trifasciata leaf extract in Wistar rats. J. Intercult. Ethnopharmacol. 6, 234-239.

Islam, F., Hossain, A., Hossain, M.G., Murshid, G.M. and Rahman, M.M. 2015. Evaluation of antioxidant, analgesic and cytotoxic activities of Typha angustata L. root. Dhaka Univ. J. Pharm. Sci. 14, 55-59.

Kokwaro, J.O. Medicinal Plants of East Africa. 2009. University of Nairobi Press.

Ksouri, R., Falleh, H., Megdiche, W., Trabelsi, N., Mhamdi, B. and Chaieb, K. 2009. Antioxidant and antimicrobial acivities of the edible medicinal halophyte Tamarix gallica L. and related polyphenolic constituents. Food Chem. Toxicol. 47, 2083-2091.

Martin-Cordero, G., Saenz, M.T. and Ayuso, M.J. 1995. Cytotoxic activity of Retama spaerocarpa. Fitoterapia. 16, 495-498.
Meyer, B.N., Ferrigni, N.R., Putnam, J.E., Jacobsen, L.B., Nichols, D.E. and McLaughlin, J.L. 1982. Brine shrimp: a convenient general bioassay for active plant constituents. Planta Med. 45, 31-34.

Mongelli, E., Desmarchelier, C. and Giulietti, A. 1995. Bioactivity of certain medicinal latexes used by the Eséejas. J. Ethnopharmacol. 47, 159-163.

Omale, J. and Okafor, P.N. 2008. Comparative antioxidant capacity, membrane stabilization, polyphenol composition and cytotoxicity of the leaf and stem of Cissus multistriata. Afr. J. Biotech. 7, 3129-3133.

Parr, A.J. and Bolwell, G.P. 2000 May. Phenols in the plant and in man. The potential for possible nutritional enhancement of the diet by modifying the phenols content or profile. J. Sci. Food Agric. 80, 985-1012.

Ruan, Z.P., Zhang, L.L. and Lin, Y.M. 2008. Evaluation of the antioxidant activity of Syzygium cumini leaves. Molecules. 13, 2545-2556.

Rwawiire, S. and Tomkova, B. 2015. Morphological, thermal, and mechanical characterization of Sansevieria trifasciata fibers. J. Nat. Fibers. 12, 201210.

Shahidi, F., Janitha, P.K. and Wanasundara, P.D. 1992. Phenolic antioxidants. Crit. Rev Food Sci Nutr. 32, $67-$ 103.

Shinde, U.A., Phadke, A.S., Nair, A.M., Mungantiwar, A.A., Dikshit, V.J. and Saraf, M.N. 1999. Membrane stabilizing activity- a possible mechanism of action for the anti-inflammatory activity of Cedrus deodara wood oil. Fitoterapia. 70, 251-257.

Sikder, M.A., Siddique, A.B., Hossian, A.K., Miah, M.K., Kaisar, M.A. and Rashid, M.A. 2011. Evaluation of thrombolytic activity of four Bangladeshi medicinal plants, as a possible renewable source for thrombolytic compounds. J Pharm Nutr Sci. 1, 4-8.

Sulaiman, M.R., Hussain, M.K., Zakaria, Z.A., Somchit, M.N., Moin, S., Mohamad, A.S. and Israf, D.A. 2008 Evaluation of the antinociceptive activity of Ficus deltoidea aqueous extract. Fitoterapia. 79, 557-561.

Sumi, S.A., Saeed, M.A.S., Hossain, A., Mia, M.S., Afrin, S. and Rahman, M.M. 2016. Investigation of the key pharmacological activities of Ficus racemosa and analysis of its major bioactive polyphenols by HPLCDAD. Evid. Based. Complement. Alternat. Med. 2016, 9.

Yang, C.M. and Russell, J.B. 1992 Dec. Resistance of proline-containing peptides to ruminal degradation in vitro. Appl. Environ. Microbiol. 58, 3954-3958.

Zhang, L.L. and Lin, Y.M. 2008. Tannins from Canarium album with potent antioxidant activity. J. Zhejiang Univ. SCIENCEB. 9, 407-415. 